ks. Wojciech Kapica

ks. Radostaw Kimsza

Politechnika Białostocka

\title{
Antropologiczne podstawy duchowości św. Jana od Krzyża
}

\section{ANTHROPOLOGICAL BASE OF THE SPIRITUALITY OF ST. JOHN OF THE CROSS}

Main Square of interest St. John of the Cross was a man in his relationship to God. For meringue these interests can create his anthropology. It moves the issue of human dignity as the image and likeness of God, who, despite the distortion of sin allows you to create a desire for union with the Creator, as a result of God's initiative. The man in the vision of St. John of the Cross is seen as a psychosomatic unity as well as diversity. Author subjected to a detailed analysis of the two spheres of human life: physical and spiritual. In the sphere of bodily focus on sensuality, which, because of their condition appears to be a hurdle in union with God and therefore calls for purification. In the spiritual realm are: the soul and the spirit, and the spiritual power of intellect, memory and will. They are of fundamental importance in the relationship of man to God. The article raises the question of "apetitos" as disordered human attachments.

Key words: spiritual theology, spirituality Carmelite, St. John of the Cross, anthropology, body - soul - spirit, the senses, "apetitos", purifications.

\section{Wstęp}

Człowiek ze swej natury jest bytem cielesno-duchowym. Na przestrzeni wieków wypracowano dualistyczną koncepcję osoby ludzkiej, 
Antropologia teologiczna która definiowała ją jako duszę i ciało oraz tę, która wskazywała na trzy czynniki konstytutywne bytu ludzkiego: ciało, duszę i ducha.

Duchowość chrześcijańska, choć w samej nazwie wydaje się koncentrować na ludzkim duchu, zajmuje się całym człowiekiem. Człowiek duchowy to ten, który jest „siedliskiem” Ducha Świętego. Trzecia Osoba Trójcy Świętej w odpowiedzi na wolną wolę człowieka integruje go, scala będące w nim konsekwencją grzechu podziały, czyniąc wciąż „człowieka nowego”, coraz to bardziej podobnego do swojego Stwórcy. O ile dusza będąc swoistą formą bytu ludzkiego czyni z człowieka podmiot pośród przedmiotów, o tyle ludzki duch rozumiany jest jako wewnętrzny wymiar duszy, jej osobowe upostaciowienie, otwierające na przyjęcie łaski, uczestnictwo w życiu Trójcy Świętej, ukierunkowanie się ku swojemu celowi nadprzyrodzonemu, uzdalniającemu duszę do wejścia w komunię z Bogiem ${ }^{1}$.

Osobiste doświadczenie życia w Bogu stworzyło tzw. szkoły duchowości, które opisują nie tylko to, co tworzy szeroko pojętą ascezę chrześcijańską, czy też mistykę, ale także fenomen człowieka to, co pozwala w nim doświadczać Boga, jego stan przed rozpoczęciem życia duchowego, często określany jak jego początek, prawdę o nim w poszczególnych etapach rozwoju duchowego, a także jego kres przebóstwienie czy też zjednoczenie się z Bogiem.

Historia duchowości chrześcijańskiej usystematyzowała sposoby życia chrześcijańskiego od jego zarania aż po współczesne nurty przeżywania obecności Boga i jednoczenia się z Nim. W XVI wieku, głównie dzięki św. Teresie od Jezusa i św. Janowi od Krzyża, została odnowiona duchowość Zakonu Karmelitańskiego, sięgająca XII wieku, palestyńskiej Góry Karmel i żyjących tam eremitów naśladujących proroka Eliasza i Maryję. Te dwa wzory duchowości karmelitańskiej wskazują przede wszystkim na kontemplację Boga i Jego tajemnic a także na uzdalniające ku temu uwarunkowania człowieka. „Człowiek nie będzie wiedział, jak ma żyć, dopóki nie pozna, kim jest [...] Agere sequitur esse, działanie wynika z tego, kim się jest [...]"'. Pierwotny charyzmat Karmelu, odnowiony przez św. Teresę i św. Jana od Krzyża wskazuje na usposobienie człowieka zdolnego do kontemplacji i tego wszystkiego, co jej służy. Wspomniany Podręcznik życia karmelitańskiego, odwołując się do listu Papieża Leona XIII do przełożonego

Por. C. Bartnik, Dogmatyka katolicka, t. 1, Lublin 2000, s. 386.

W. Stinissen, Ukryci $w$ miłości. Podręcznik życia karmelitańskiego, Kraków 2013, s. 13 . 
generalnego Zakonu Karmelitańskiego wskazuje na trzy czynniki warunkujące kontemplację: milczenie, samotność i umartwienie ${ }^{3}$.

Już samo studium nad duchowością stworzoną przez św. Jana od Antropologia teologiczna Krzyża pozwala zauważyć jego zainteresowanie się człowiekiem nie tylko w wymiarze życia duchowego, ale także strukturalnego, wpisanego w całokształt badań nad jego „drogą do zjednoczenia z Bogiem”. Źródłem opisu fenomenu człowieka uzewnętrzniającego się w zdolności tworzenia głębokiej więzi ze Stwórcą było jego osobiste doświadczenie, przeżycie mistyczne, zjednoczenie się stworzenia ze Stwórcą. Inspirowało ono do stawiania pytań na wskroś antropologicznych o możliwość zjednoczenia się stworzenia, które ze swej cielesno-duchowej natury jest skazane na pośrednictwo materii, z niematerialnym Bogiem, a także o celowość tego zjednoczenia w doczesności, mając na uwadze cel istnienia ludzkiego, jakim jest wieczność z Bogiem ${ }^{4}$.

Osobiste doświadczenie św. Jana od Krzyża było echem jego przekonania czerpiącego z natchnionego Słowa Biblii: „idąc za Pismem Świętym nie możemy zbłądzić, bo przez nie przemawia Duch Święty"5. Próbował więc osobiste doświadczenie Boga odnieść do doświadczeń biblijnych bohaterów badając ich relację z Stwórcą, odkrywając ich otrzymaną od Boga godność, wyniesienie, ale także i grzeszność. Fundamentalnym stał się dla niego stwórczy akt człowieka noszącego w sobie Boży obraz i Boże podobieństwo - warunek pozaestetycznego piękna człowieka, uwarunkowanego trwaniem w Bożej miłości. Bóg stwarza go na swoje podobieństwo, jednak człowiek jako obraz Boga jest na tyle piękny, na ile trwa w Bogu, w Jego łasce. To ona umożliwia człowiekowi jednoczenie się z Bogiem, dialog z Nim, nieustannie pogłębiającą się relację. Ta zaś inspiruje go do twórczych relacji ze stworzonym światem i pomieszczonym w nim człowieku. $\mathrm{W}$ ten sposób następuje proces przebóstwienia człowieka, jego nieustanne upodobnianie się do Boga ${ }^{6}$ aż do osiągnięcia pełni człowieczeństwa, do doświadczenia Apostoła Narodów: „ Już nie ja żyję, ale żyje we mnie Chrystus” (Ga 2, 20); „Dla mnie żyć to Chrystus” (Flp 1, 21).

\section{Tamże.}

4 Por. R. S. Niziński, Zjednoczenie z Bogiem jako moment petnego narodzenia osoby ludzkiej..., Filozofia Chrześcijańska 2(2005), s. 193-194.

5 Droga na Górę Karmel, Prolog, 2.

6 Por. J. W. Gogola, Teologia Komunii z Bogiem, Kraków 2001, s. 77-78. 
Antropologia teologiczna

\section{Godność człowieka a zjednoczenie z Bogiem}

Powołanie człowieka realizuje się w konkretnym świecie, w którym Bóg uzdalnia go do odkrycia zamysłu swej miłości. To przekonanie towarzyszyło św. Janowi od Krzyża i na nim budował on tzw. oblubieńczą antropologię, która bierze swój początek z komunii Boskiego Bytu i wewnątrztrynitarnej miłości. Jest ona źródłem istnienia ludzkiego i jego spełnieniem oraz ostatecznym celem:

Tajemnica człowieka wyjaśnia się naprawdę dopiero w tajemnicy Słowa Wcielonego. Albowiem Adam, pierwszy człowiek, był figurą przyszłego, mianowicie Chrystusa Pana. Chrystus, nowy Adam, już w samym objawieniu tajemnicy Ojca i Jego miłości objawia w pełni człowieka samemu człowiekowi i okazuje mu najwyższe jego powołanie ${ }^{7}$.

Natura ludzka od samego początku została przeznaczona do komunii z Bogiem. Bóg - Miłość stwarza człowieka na swój obraz i podobieństwo (por. $R d z 1,26$ ), powołując go do wspólnoty ze sobą. W swej miłości przekracza samego siebie, udziela się na zewnątrz i staje się naturalnym środowiskiem duszy, obdarzając ją łaskami i poruszeniami duchowymi. „Rozumie zatem dusza, że w Bogu ma swoje życie naturalne, biorąc z Niego swój byt, i w Bogu ma swoje życie duchowe przez miłość, która go kocha"8. Z tego względu człowiek może być cały w Bogu, może się cały w nim zanurzyćp

Odkrywając miłość Boga człowiek odpowiada pragnieniem upodobnienia się do Niego i zaczyna przeżywać komunię z Nim poprzez wprowadzanie wewnętrznego ładu - rezultatu wysiłku ascetycznego i życia w łasce uświęcającej. I choć odpowiedzi udziela człowiek, to ostatecznie twórcą uporządkowanych relacji w człowieku i z nim jest Bóg. Stan pierwotnej harmonii i każdej innej zostaje zakłócony grzechem. Wówczas

człowiek [...] pozwolił, by zamarło w jego sercu zaufanie do Stwórcy i nadużywając swojej wolności, okazał nieposłuszeństwo przykazaniu Bożemu. Na tym polegał pierwszy grzech człowieka. W następstwie tego faktu każdy grzech będzie nieposłuszeństwem wobec Boga i brakiem zaufania do Jego dobroci ${ }^{10}$.

\section{KDK 22.}

PD 8, 3.

Por. L. Wianowski, Ku petni w Bogu. Godność człowieka..., „Karmel” 2(2000), s. 11-12.

Katechizm Kościoła Katolickiego (dalej: KKK) 397. 
Poprzez każde zło następuje zerwanie relacji z Bogiem, każdej innej a także wykrzywienie prawdy o pierwotnym pięknie człowieka. Fakt grzechu i jego konsekwencje pozwala zrozumieć pierwotna komunia Antropologia teologiczna z Bogiem. Człowiek przebywając z Nim posiada życie, grzech zaś jest jego przeciwieństwem: „Albowiem zapłatą za grzech jest śmierć” (Rz $6,23)$. W tym kontekście grzech nabiera charakteru na wskroś personalistycznego: „Oddalenie się od Boga, jest grzechem”"11, zakłóceniem relacji pomiędzy osobami - Bogiem i człowiekiem, wolnym aktem sprzeciwu stworzenia wobec Stwórcy, okazaniem Mu wrogości. Chodzi więc tu o coś znacznie więcej niż tylko przekroczenie norm i praw.

Sprzeciw ten jest tragedią zarówno Boga jak i człowieka. Poemat św. Jana od Krzyża Pasterz przedstawia sytuację Stwórcy - Pasterza, który dzieląc się miłością, został odrzucony przez człowieka - pasterkę: „Biedny ja! - woła - biedny z tej przyczyny, /Że moją miłość zdeptała tak dumnie, /Że szczęścia ze mną nie chciała, ni u mnie, /Miłość mnie karze i dręczy bez winy"12.

Jednakże grzech to przede wszystkim dramat człowieka. Neguje jego naturę, wprowadza rozdźwięk i dysharmonię między nim a Stwórcą, powoduje wewnętrzną dezintegrację człowieka, której efektem jest chaos we władzach duchowych i zmysłowych, skłonność i pożądliwość przeciwne porządkowi ustanowionemu przez Boga. „Po grzechu pierworodnym dusza jest rzeczywiście jakby niewolnicą w tym ciele śmiertelnym, poddana naturalnym namiętnościom i pożądaniom" ${ }^{13}$. Oznacza to, że natura ludzka po grzechu, sama w sobie dobra, doznała poważnego uszczerbku ${ }^{14}$. Święty Jan od Krzyża pisze o stanie natury człowieka po grzechu w Pieśni duchowej: „Przez owoc zakazanego drzewa w raju natura ludzka została w Adamie skażona i stracona [...]"15. Przy czym ,stracenie natury" odnosi się do jej stanu pierwotnego, „obrazu i podobieństwa” Boga.

Dramatem absolutnym byłby grzech oznaczający kres historii człowieka. „Po swoim upadku człowiek nie został opuszczony przez Boga. Przeciwnie Bóg wzywa go i zapowiada mu tajemnicze zwycięstwo nad złem oraz podniesienie go z upadku" ${ }^{\prime 16}$, które jest początkiem kolejnego etapu „miłosnej historii” Boga do człowieka, wyrażającej się

11 Droga na Górę Karmel, III, 18, 1.

12 Pasterz, 4.

13 Droga na Górę Karmel, 15, 1.

14 Por. A. Ruszała, Grzech pierworodny jako dramat Boga i człowieka, „Karmel” 1(1999), s. 24-28.

15 Pieśn duchowa, 23, 2.

KKK 410. 
Antropologia teologiczna

w dramatycznym jego poszukiwaniu. Prawdę tę wyraża pytanie, jakie Bóg wypowiada po grzechu pierworodnym: „Adamie gdzie jesteś?” $(\mathrm{Rdz} 3,9)$.

Poszukiwanie człowieka przez Boga osiąga swój szczyt w wydarzeniu Jezusa Chrystusa, w Jego Wcieleniu i Odkupieniu. W nich rehabilituje On całkowicie rozbitego poprzez grzeszne czyny człowieka, objawiając w ten sposób swoją bezwarunkową miłość. To podniesienie człowieka z upadku nie jest celowe samo w sobie, ale najpełniej realizuje się w propozycji oblubieńczej relacji. W wyrażeniu tej prawdy św. Jan od Krzyża posługuje się kategoriami języka oblubieńczego: w sposób wolny, bezwarunkowy i skuteczny Bóg próbuje pociągnąć człowieka ku sobie. To On jest zawsze inicjatorem spotkania: „Najpierw trzeba wiedzieć, że jeśli dusza szuka Boga, to o wiele bardziej Umiłowany jej szuka. I jeśli ona śle do Niego swoje miłosne pragnienia [...] to On wysyła jej również zapach swych olejków, którymi ją pociąga i porywa do siebie" 17 .

W teologii św. Jana od Krzyża Odkupienie, obok stworzenia jest najwyższym wyrazem miłości Boga do człowieka. W nim Stwórca przygarnia stworzenie i daje mu kolejną szansę wzniesienia się na wyższy poziom miłości ${ }^{18}$. Prawdę tę św. Jan od Krzyża odczytuje w tajemnicy krzyża, określanego jako klucz do odkrycia prawdziwej mądrości:

[...] jak przez owoc zakazanego drzewa w raju natura ludzka została w Adamie skażona i stracona, tak na drzewie Krzyża została odkupiona i naprawiona. Tam bowiem zwrócił jej Bóg swoją łaskę i podał rękę miłosierdzia. Przez swoją mękę i śmierć usunął rozdział, jaki wprowadził grzech pierworodny między człowieka i Boga ${ }^{19}$.

Dzieło Wcielenia i Odkupienia wprowadza człowieka na nowo w stan komunii z Bogiem i leczy spowodowane przez grzech zranienia. Człowiek uczestniczy w tym dziele poprzez chrzest, który „nie tylko oczyszcza ze wszystkich grzechów, lecz także czyni neofitę «nowym stworzeniem», przybranym synem Bożym, który stał się «uczestnikiem Boskiej natury», członkiem Chrystusa, a z Nim «współdziedzicem», świątynią Ducha Świętego" "20. W ten sposób człowiek, uzyskuje status syna: „A zatem nie jesteś już niewolnikiem, lecz synem. Jeżeli zaś synem, to i dziedzicem z woli Bożej" (Ga 4, 7). Obdarowany na chrzcie człowiek staje się udziałowcem dóbr prowadzących do obcowania

\footnotetext{
$17 \quad \dot{Z} y w y$ płomień miłości, 3, 28.

18 Por. L. Wianowski, Ku petni w Bogu. Godność człowieka..., dz. cyt., s. 13.

19 Pieśn duchowa, 23, 2.
}

Katechizm Kościoła Katolickiego, 1265. 
z osobami Trójcy Świętej, w uświęceniu i łasce. Chrzest stanowi więc kluczowy moment życia nadprzyrodzonego. Jest duchowym narodzeniem się do życia $\mathrm{w}$ zjednoczeniu z Bogiem ${ }^{21}$.

Wymienione etapy nie eliminują się wzajemnie. Co więcej wciąż się przenikają i pozostają cały czas obecne na drodze zjednoczenia. Grzech zrywa jedność z Bogiem, lecz nie niszczy Boskiego obrazu w człowieku. Odkupienie przywraca łaskę, nie likwidując przy tym żądz i namiętności człowieka. Życie z Bogiem podlega ciągłemu rozwojowi, w ramach wolnego i bolesnego procesu. Należy tu podkreślić wolność obdarowywanego ${ }^{22}$. Jest ona konsekwencją „duszy duchowej”, różniącej człowieka od innych stworzeń. Według Jana od Krzyża „być duchem" oznacza posiadać duchową wolę, rozum i pamięć ${ }^{23}$. Człowiek jest jednak duchem ucieleśnionym, gdzie duch i ciało są jednością. Implikuje to możliwość wyboru poziomu, na którym będzie egzystował, zaczynając od wartości ziemskich, cielesnych przez moralne aż do samego Boga ${ }^{24}$. W konsekwencji z jednej strony istnieje pokusa odrzucenia obranej drogi postępu, z drugiej zaś człowiek doświadczający swej godności, wielkości i transcendencji wobec stworzenia jest niejako „zdeterminowany” do dalszego poszukiwania Boga, który chce podnieść ją do stanu nadprzyrodzonego ${ }^{25}$. Ta godność jest tak wielka, że „Jedna tylko myśl człowieka ma większą wartość niż świat cały, dlatego Bóg tylko jest jej godzien"26.

Cała antropologia św. Jana od Krzyża bierze swój początek w Bogu i w nim się kończy ${ }^{27}$ :

Związek Boga i stworzenia jest absolutny podobnie jak drzewa i jego korzeni. Bóg jest ostateczną i jedyną racją wszelkiego istnienia. Człowiek uczestnicząc $\mathrm{w}$ tym istnieniu przez swoją taką właśnie a nie inną strukturę bytową wchodzi w relację najbardziej fundamentalnej zależności, dzięki niej zaistniał i jej zawdzięcza trwanie w istnieniu ${ }^{28}$.

${ }^{21} \quad$ Por. L. Wianowski, Ku petni w Bogu. Godność człowieka..., dz. cyt., s. 8-9.

Por. F. R. Salvador, Mistyk i nauczyciel, Święty Jan od Krzyża, I, Poznań 2008, S. 236-237.

Por. Żywy płomień miłości, 3, 18.

Por. A. Rachmajda, Gtębia człowieka u Jana od Krzyża, „Zeszyty Karmelitańskie" 3(2002), s. 70-71.

Por. L. Wianowski, Ku petni w Bogu. Godność człowieka..., dz. cyt., s. 14 .

Sentencje, [w:] Święty Jan od Krzyża. Dzieła, Kraków 1998, s. 104.

Por. M. Chmielewski, Przebóstwienie człowieka wedtug świętego Jana od Krzyża, „Ateneum Kapłańskie” 1(1991), s. 56. 
Antropologia teologiczna

Dlatego zjednoczenie z Bogiem jawi się jako fundamentalna aspiracja człowieka, dążenie, które powinno go nieustannie przenikać: „Przecież dla tej miłości zostaliśmy stworzeni”"29. Rozumienie tego dążenia tylko jako planu ascetycznego, bądź osobistej gorliwości człowieka byłoby nieporozumieniem ${ }^{30}$.

\section{Człowiek - jedność i różnorodność}

W doktrynie św. Jana od Krzyża osoba ludzka jawi się w podwójnej perspektywie: w aspekcie metafizycznym, gdzie człowiek jest przedstawiony jako byt cielesno-duchowy, jedność ontyczna posiadająca właściwe władze i dynamizmy oraz moralnym, w jego relacji do dobra. Wymiary te przenikają się i uzupełniają ${ }^{31}$.

Jan od Krzyża ukazywał całościową koncepcję człowieka za pomoca trzech symboli ${ }^{32}$. Pieśń duchowa przedstawia odnoszące się do człowieka metafory: „wyniosłego szczytu”33, ,jestestwa”34 i „miasta - twierdzy" 35 . Przyglądając się z najszerszej perspektywy elementom zawartym w tych modelach można stwierdzić, że człowiek posiada dwie podstawowe sfery: cielesną (określaną również jako niższą bądź zewnętrzną) i duchową (zamiennie zwaną wyższą lub wewnętrzną) ${ }^{36}$. Ujmują one człowieka jako żyjącą całość, która składa się z różnych elementów bytowych. Każdy z czynników, zaczynając od wegetatywnego, a kończąc na duchowym, jest potrzebny w tej całości i dopiero przez nią uzyskuje znaczenie ${ }^{37}$. Wyżej przedstawione „rozwarstwienie” ułatwia zrozumienie procesu duchowego przez jaki przechodzi człowiek. Bóg w tym procesie towarzyszy człowiekowi w jego stopniowym przechodzeniu z „królestwa zmysłów”, do „królestwa ducha”38. Podział

Pieśń duchowa, 29, 3.

Por. F. R. Salvador, Mistyk i nauczyciel..., dz. cyt., s. 238.

Por. M. Kiwka, Świętego Jana od Krzyża myśli o człowieku. Z antropologii św. Jana od Krzyża, „Wrocławski Przegląd Teologiczny” 1(1996), s. 90.

Por. A. Ruszała, Ze świętym Janem od Krzyża ku zjednoczeniu z Bogiem. Afektywność na drodze do zjednoczenia z Bogiem wedtug św. Jana od Krzyża, Kraków 1999, s. 41.

Por. Pieśń duchowa, 16, 10.

Por. tamże, 28, 4.

Por. tamże, 18, 7.

Por. M. Kiwka, Świętego Jana od Krzyża myśli o człowieku..., dz. cyt., s. 90.

Por. S. Witek, Teologia życia duchowego, Lublin 1986, s. 44.

Por. F. R. Salvador, Mistyk i nauczyciel..., dz. cyt., s. 251. 
człowieka na wyżej wymienione sfery stanowi zrąb antropologii św. Jana od Krzyża ${ }^{39}$.

\section{Sfera Cielesna}

Sferę cielesną człowieka stanowi ciało oraz zmysły, które są jego władzami. W niej człowiek wchodzi w relację ze światem materialnym.

Ciało jako najbardziej zewnętrzny element, dzięki któremu człowiek staje się widzialny, w połączeniu z duszą tworzy jeden podmiot ludzki. Dzięki niemu dusza ma możliwość poznania świata zewnętrznego, ponieważ: „[...] nic nie może czynić sama bez pomocy zmysłów cielesnych" 40 .

Święty Jan od Krzyża doceniał wartość ciała i miał na nie głęboko chrześcijańskie spojrzenie ${ }^{41}$. Podstawowym motywem takiej interpretacji ciała jest Wcielenie Chrystusa ${ }^{42}$. Bóg-Człowiek sprawił, że także ciało ludzkie powołane jest do uczestnictwa w życiu Bożym. Spojrzenie Jana od Krzyża na ludzkie ciało jest bardzo realistyczne: dostrzegał jego piękno, ale także ograniczenia i niemoc ${ }^{43}$.

Zmysły, bezpośrednio związane z ludzkim ciałem, obok władz duchowych są jednym z dwóch sposobów kontaktu człowieka ze światem. Święty podkreślał ich funkcję w Drodze na Górę Karmel:

Dusza bowiem nie może działać ani odbierać skutków działania inaczej, jak tylko drogą tych dwóch rodzajów władz: zmysłowych i duchowych. Za pomocą władz zmysłowych może rozważać, szukać i dochodzić do poznania przedmiotów; za pomocą zaś władz duchowych może radować się z wiadomości przez te władze otrzymanych ${ }^{44}$.

Zmysły pełnią więc funkcję recepcyjną i komunikatywną ${ }^{45}$. Mistyk był świadomy tej roli i wyraził ją w Drodze na Górę Karmel, gdzie porównywał duszę do czystej tablicy, która jest zapisywana dzięki informacjom dostarczanym przez zmysły: ,[...] dusza, w chwili gdy ją Bóg tchnie w ciało, jest jak tablica gładka i czysta, i niczym nie

Por. D. Wider, Do petni miłości, Kraków 1985, s. 13.

40 Żywy płomień mitości, 1,9 .

$41 \quad$ Por. A. Ruszała, Ze świętym Janem od Krzyża ku zjednoczeniu z Bogiem..., dz. cyt., s. 48-50.

$42 \quad$ Por. S. Witek, Teologia życia duchowego, dz. cyt., s. 47.

43 Por. A. Ruszała, Ze świętym Janem od Krzyża ku zjednoczeniu z Bogiem..., dz. cyt., s. 51.

$44 \quad$ Droga na Górę Karmel, II, 14, 6.

45 Por. J. W. Gogola, Teologia Komunii z Bogiem, dz. cyt., s. 79-80.
} 
Antropologia teologiczna

zapisana i jeżeli czegoś nie pozna za pomocą zmysłów, inną drogą zwyczajnie nic jej nie zostanie udzielone" ${ }^{46}$. W tym samym miejscu Święty porównywał duszę zamkniętą w ciele do ciemnego więzienia. Światło dociera tam tylko i wyłącznie poprzez okna zmysłów. Jest to wyraźne nawiązanie do Arystotelesowskiej zasady: „Niczego nie ma w intelekcie, co wcześniej nie pojawiłoby się w zmysłach". W pismach Jana od Krzyża świat zmysłowy podzielony jest na dwie grupy: zmysłów zewnętrznych i wewnętrznych ${ }^{47}$.

Zmysły zewnętrzne to te, których działanie jest bezpośrednio powiązane z ciałem. Są to: wzrok, słuch, węch, smak i dotyk ${ }^{48}$. Kolejność, w jakiej się pojawiają nie jest przypadkowa. Na początku zawsze znajdujemy wzrok lub słuch jako te, które według św. Jana od Krzyża są najbardziej „uduchowiane”, a tym samym mają największą zdolność symbolizowania przeżyć duchowych ${ }^{49}$. Wzrok staje się pomocą do wyrażenia doznań duchowych, które popularnie nazywane są „widzeniami”. Słuch pełni również bardzo ważną rolę. Według św. Jana od Krzyża jest bardziej „duchowy”, w odróżnieniu od innych zmysłów ${ }^{50}$. W dużej mierze od woli człowieka zależy, co widzi i czego słucha. W ten sposób może ubogacać lub zubażać swoją duchowość.

W skład zmysłów wewnętrznych wchodzą: pamięć, wyobraźnia i fantazja. W niektórych swoich dziełach Jan od Krzyża pomijał pamięć, koncentrując się na wyobraźni i fantazji, które w znaczny sposób mogą przynosić szkodę życiu duchowemu człowieka:

Trzeba wiedzieć, że zmysły, które tu szczegółowo omawiamy, to dwa organiczne zmysły wewnętrzne: wyobraźnia i fantazja. Zmysły te służą sobie wzajemnie w sposób uporządkowany: jeden działa posługując się wyobrażeniami, drugi przez fantazję tworzy obrazy. [...] Zatem to wszystko, co zmysły mogą pojąć i ukształtować, określamy mianem: wyobrażenia lub wytwory fantazji. Są to kształty, które przez obrazy, czy formy cielesne przedstawiają się zmysłom ${ }^{51}$.

Wyobraźnia jest więc bardziej bierna, a jej rolę można określić jako odtwórczą. Tworzy ona wyobrażenia rzeczy, które wcześniej zostały odebrane za pomocą zmysłów zewnętrznych. Inaczej jest w przypadku

\footnotetext{
$46 \quad$ Droga na Górę Karmel, I, 3, 3.

47 Por. M. Kiwka, Świętego Jana od Krzyża myśli o człowieku..., dz. cyt., s. 91.

48 Por. Pieśń duchowa, 18, 7.

Por. M. Kiwka, Świętego Jana od Krzyża myśli o człowieku..., dz. cyt., s. 91.

Por. A. Ruszała, Ze świętym Janem od Krzyża ku zjednoczeniu z Bogiem..., dz. cyt., s. 55-56.

Droga na Górę Karmel, II, 12, 3.
} 
fantazji, która opierając się na wyobraźni może tworzyć zupełnie nowe wyobrażenia, nawet takie, które nie istnieją. Fantazja potrzebuje więc wyobraźni. Oba zmysły spełniają bardzo ważną rolę, ponieważ łączą ze sobą świat materialno-zmysłowy i intelektualno-duchowy ${ }^{52}$. Według św. Jana od Krzyża są one przydatne na początku życia duchowego jako pomoc w modlitwie myślnej ${ }^{53}$. Pozwalają niejako uczestniczyć w wydarzeniach medytowanych, szczególnie ewangelicznych:

Zadaniem tych dwu władz jest pomagać w rozmyślaniu, które jest działaniem dyskursywnym z pomocą form, kształtów i figur utworzonych przez wspomniane zmysły [zewnętrzne]. Są to rozmyślania takie, jak np. przedstawienie sobie Chrystusa na krzyżu, przy słupie kaźni lub w innej tajemnicy Jego Męki; wyobrażenie sobie Boga w wielkim majestacie, siedzącego na tronie; rozważanie i przedstawianie sobie chwały niebieskiej jako najjaśniejszego światła, itd. ${ }^{54}$

Niestety zmysły te są podatne nie tylko bezpośredniemu oddziaływaniu Boga, ale także ma do nich dostęp szatan:

Trzeba także wiedzieć, że jak pięć zmysłów zewnętrznych przedkłada i przedstawia obrazy i pojęcia swoich przedmiotów zmysłom wewnętrznym, tak w sposób nadprzyrodzony, bez udziału zmysłów zewnętrznych, Bóg i szatan przedstawić może te same obrazy i pojęcia tylko o wiele piękniejsze i doskonalsze ${ }^{55}$.

W efekcie Bóg posługuje się nimi, by wprowadzić człowieka w świat nadprzyrodzonej mądrości, szatan zaś tworząc na płaszczyźnie zmysłów pozory dobrych wizji w rezultacie pragnie sprowadzić, używając języka św. Jana od Krzyża, duszę na manowce grzechu ${ }^{56}$.

Jan od Krzyża był świadomy tego, że sfera zewnętrzna człowieka charakteryzuje się gwałtownością i nienasyconością pożądań, które niekontrolowane czynią zeń niewolnika:

Zrozumiałe jest, że pożądania dręczą i trudzą duszę. Są one jak niesforne i uprzykrzone dzieci, które ustawicznie proszą matkę o to czy owo, a nigdy im nie dosyć. Ileż to nadręczy się i trudzi człowiek szukający chciwie skarbu. Tak również dręczy się i trudzi dusza w zdobywaniu

Por. A. Ruszała, Ze świętym Janem od Krzyża ku zjednoczeniu z Bogiem..., dz. cyt., s. 56-58.

Por. M. Kiwka, Świętego Jana od Krzyża myśli o człowieku..., dz. cyt., s. 91.

Droga na Górę Karmel, II, 12, 3.

Tamże, II, 16, 3.

Por. tamże, II, 16, 3. 
Antropologia teologiczna

tego, czego domagają się od niej pożądania. A chociaż w końcu i zdobędzie to, dręczy się jednak nie znalazłszy zaspokojenia ${ }^{57}$.

Zmysły nie dosięgają istoty rzeczy, a w sprawach duchowych wykazują się ignorancją: „Albowiem zmysły ciała jeszcze mniej pojmują rzeczy duchowe, aniżeli zwierzę pojmuje rzeczy rozumne"58. Największy brak sfery zmysłowej Jan od Krzyża widział w tym, że: „Bóg nie podpada pod zmysł”, słowy bowiem nie pojmuje tego, co jest z Bożego Ducha. Głupstwem mu się to wydaje i nie może tego pojąć, bo tylko Duchem można to zrozumieć" (1 Kor 2, 14). Oczywiście celem zmysłów nie jest zdolność rozumienia spraw Bożych, jednak mimo wszystko chcą one władać całym życiem człowieka. Aby praca, jaką wykonują zmysły była człowiekowi pożyteczna, musi w nim istnieć hierarchia wewnętrzna, w której świat zmysłów nie może odgrywać głównej roli ${ }^{60}$. Nie chodzi jednak o wyniszczanie i wyzbywanie się tego, co należy do ludzkiej natury, ponieważ w ziemskim życiu jest to niemożliwe. Świętemu chodziło raczej o harmonijność, podporządkowanie tego, co niższe w człowieku sferze wyższej. Myśl Jana od Krzyża w tych kwestiach można podsumować następująco: „Tam, gdzie panują zmysły człowiek staje się mniej człowiekiem, po prostu odczłowiecza się"61, niejako degraduje siebie do bytu materialnego. Na tej płaszczyźnie widoczne jest rozróżnienie św. Pawła pomiędzy człowiekiem duchowym i cielesnym, zmierzającym ku życiu i ku śmierci.

\section{Sfera duchowa}

Sfera duchowa jest drugim elementem człowieka, stanowiącym o wyższym, w porównaniu do innych istot żywych stopniu jego egzystencji, a także najbardziej właściwym wymiarem ludzkiego bytu, który przekracza materię i zmysły. Tam, gdzie występuje duch, tam też jest człowiek $^{62}$. Wypowiadając się na temat duchowej części człowieka, Jan

Tamże, I, 6, 6 .

Tamże, II, 11, 2.

Żywy płomień miłości, 3, 73 .

Por. F. R. Salvador, Święty Jan od Krzyża, pisarz-pisma-nauka, Kraków 1998, S. 406-411.

61 Tamże, s. 407.

62 Por. S. Witek, Teologia życia duchowego, dz. cyt., s. 53.
} 
od Krzyża miał na myśli duszę i ducha (często traktuje je jako jedność, „dusza - duch”), oraz władze duchowe: intelekt, pamięć i wolę ${ }^{63}$.

Święty Jan od Krzyża stosował „duchową topografię”, wyróżniając Antropologia teologiczna pewne obszary w sferze wewnętrznej człowieka. Są nimi: „korzeń duszy”, „substancja duszy”, „środek duszy” i „dno duszy”. Pojęcia te ukazują jednoczenie się człowieka z Bogiem, zależność ontyczną stworzenia od Stwórcy. Bóg przebywa w duszy, choć nie może być bezpośrednio poznany: „Należy wiedzieć, że Bóg we wszystkich duszach przebywa ukryty w samej ich substancji, gdyż gdzie indziej nie mógłby istnieć" ${ }^{4}$. Spotkanie Boga z człowiekiem może się odbyć dzięki „korzeniom Boga”, które są w człowieku ${ }^{65}$. Bezwarunkowym staje się w nim zaangażowanie woli. Ona warunkuje każdy ludzki czyn. Święty był świadomy tego, że te klasyfikacje mają charakter metaforyczny ponieważ: „[...] dusza jako duch, nie ma ani długości, ani szerokości, ani wysokości lub jakiejś mniejszej lub większej głębi w swej istocie, tak jak je mają ciała posiadające wymiary" "66. Rozróżnienia mają na celu podkreślenie w człowieku obszarów granicznych, gdzie może nastąpić spotkanie $\mathrm{z}$ Bogiem ${ }^{67}$.

Podobnie jak sfera cielesna człowieka jest uposażona we władze zmysłowe, tak również sfera duchowa posiada określone władze, są nimi: intelekt, pamięć i wola, które Święty nazywał „otchłaniami duszy”. Dusza stanowi podstawę do ich działania: „Tymi otchłaniami są: pamięć, rozum i wola. Są one tak głębokie, jak wielkie skarby zdołają pomieścić i nic ich nie potrafi zapełnić, tylko nieskończoność”68. To im człowiek zawdzięcza kontakt z rzeczywistością, który odbywa się w sposób jasny, wyraźny i refleksyjny ${ }^{69}$.

Rozum wiąże się z problemem poznania intelektualnego. Według św. Jana od Krzyża poznanie to polega na dojściu do substancji, która warunkuje byt. W tym różni się od poznania zmysłowego, które zatrzymuje się na zmiennych przypadłościach, które objawiają substancję. Intelekt porównywany jest do odlewającego żelazne figury rzemieślnika: „Rzemieślnik odlewający figury z żelaza jest obrazem

63 Por. A. Ruszała, Ze świętym Janem od Krzyża ku zjednoczeniu z Bogiem..., dz. cyt., s. 62.

$64 \quad$ Żywy płomień miłości, 4, 14.

65 Por. M. Kiwka, Podstawy relacji..., dz. cyt., s. 131.

66 Żywy płomień miłości, 1, 10.

67 Por. M. Kiwka, Podstawy relacji..., dz. cyt., s. 124.

68 Żywy płomień miłości, 3, 18.

Por. F. R. Salvador, Święty Jan od Krzyża, pisarz-pisma-nauka, dz. cyt., s. 416. 
Antropologia teologiczna rozumu, którego zadaniem jest tworzyć pojęcia i oczyszczać je z rdzy wyobrażeń i złudzeń"70. Zajmuje się więc oczyszczaniem wyobrażeń zmysłowych ze szczegółów i tworzeniem pojęć ogólnych. Wszystko to jest możliwe dzięki intelektowi czynnemu, który posługuje się formami, fantazją i wrażeniami władz cielesnych. Święty wyróżnia również intelekt bierny, przyjmujący ogólne pojęcia wytworzone przez intelekt czynny. Poznanie rozbite jest więc na kilka etapów: najpierw obiekt przyjmują zmysły zewnętrzne, następnie zmysły wewnętrzne tworzą jego wyobrażenia, intelekt czynny oczyszcza te wyobrażenia i wydobywa z nich pojęcia ogólne, które na końcu procesu przyjmowane są przez intelekt bierny ${ }^{71}$.

Istnieje jeszcze inny rodzaj poznania przez człowieka - nadprzyrodzony. W nim rozum przyjmuje pojęcia i idee drogą nadprzyrodzoną, jako łaskę:

Trzeba wiedzieć, że umysł dwoma sposobami może nabywać pojęć i poznań: drogą naturalną i nadprzyrodzoną. Droga naturalna to wszystko co rozum może pojąć, czy to za pośrednictwem zmysłów, czy sam przez siebie. Droga nadprzyrodzona to wszystko co rozumowi zostaje udzielone ponad miarę jego zdolności i możliwości naturalnych ${ }^{72}$.

Za pomocą tych dwóch rodzajów poznania człowiek może wejść w relacje z otaczającym światem, z samym sobą, jak również z Bogiem. W tym miejscu trzeba dodać, że rozum sam z siebie nie może poznać istoty Boga, zawsze będzie to poznanie niepełne ${ }^{73}$ :

Wszystko, co wyobraźnia może przedstawić a umysł pojąć i zrozumieć o Bogu w tym życiu nie jest i nie może być najbliższym środkiem do zjednoczenia z Nim. Rozum bowiem może pojąć tylko to, co odbiera z kształtów i wyobrażeń podpadających pod zmysły. A ponieważ te rzeczy nie mogą być środkiem właściwym, więc nie można tu wykorzystać zdolności naturalnej. Co zaś do rzeczy nadprzyrodzonych, możliwych do osiągnięcia $\mathrm{w}$ tym życiu, to rozum $\mathrm{z}$ natury swojej nie ma dyspozycji ani zdolności, by osiągnąć w więzieniu ciała jasne poznanie Boga. Poznanie to bowiem jest niemożliwe za życia trzeba więc albo wpierw umrzeć, albo pozostać z dala od niego ${ }^{74}$.

70 Droga na Górę Karmel, II, 8, 5.

Por. A. Ruszała, Ze świętym Janem od Krzyża ku zjednoczeniu z Bogiem..., dz. cyt., s. 67-68.

Droga na Górę Karmel, II, 10, 2.

Por. A. Ruszała, Ze świętym Janem od Krzyża ku zjednoczeniu z Bogiem..., dz. cyt., s. 68-69. 
W tym przypadku rozstrzygnięciem problemu związanego z poznaniem jest wiara, która ukazuje nam to, czego nie może pojąć rozum ${ }^{75}$. Ostatecznie pełne poznanie człowieka może się dokonać tylko przy Antropologia teologiczna pomocy wiary i rozumu. Poznanie rozumowe, w zetknięciu z tym, co transcendentne, napotyka na nieprzekraczalną granicę, zaś wyznawana wiara szuka zrozumienia. Tak więc:

Wiara i rozum (Fides et ratio) są jak dwa skrzydła, na których duch ludzki unosi się ku kontemplacji prawdy. Sam Bóg zaszczepił w ludzkim sercu pragnienie poznania prawdy, którego ostatecznym celem jest poznanie Jego samego, aby człowiek - poznając Go i miłując - mógł dotrzeć także do pełnej prawdy o sobie ${ }^{76}$.

Pamięć ma zdolność gromadzenia wszystkiego, co człowiek przeżywa. Stanowi to, według św. Jana od Krzyża złożony problem, ponieważ jest ona zmysłowa i duchowa. Zadaniem pamięci duchowej, jak i pamięci w ogólności jest przywołanie do świadomości rzeczy, osób, pojęć, zdarzeń, które wcześniej istniały w duszy, lecz zostały już zapomniane ${ }^{77}$. Gdy chodzi o poruszenia i uczucia czysto duchowe

przypomina [je] sobie pamięć nie za pomocą jakiejś formy, obrazu, albo figury wyciśniętej na duszy, jako że nie mają ich te dotknięcia i uczucia zjednoczenia ze Stwórcą, lecz za pomocą skutku, tj. światła, miłości, rozkoszy, odnowienia duchowego itd. Za każdym razem, gdy pamięć je wspomina, odnawia się w niej coś z owych przeżyćc ${ }^{78}$.

Dlatego też pamięć w życiu duchowym odgrywa podwójną rolę: przywołuje „pociechy duchowe” w chwilach utrapień i wspomnienie stanu duszy po grzechu w czas doświadczenia pokusy. Jednakże pamięć o grzechu czy wewnętrznym zranieniu należy odróżnić od ich realnego istnienia. Pamięć o chorobie nie znaczy tego samego, co fizyczna niemoc.

Drugą ważną funkcją pamięci w ogólności, a szczególnie pamięci duchowej jest gromadzenie i utrwalanie tego, co człowiek przeżywa, jego planów na przyszłość ${ }^{79}$. Pomaga to w jego walce o trwałą więź z Bogiem. Dzięki tej funkcji pamięci człowiek ma możliwość powrotu do pierwotnej gorliwości o sprawy Boże. Ważne jest, by unikać pochłaniania przez pamięć wielu wspomnień, a zostawić w niej miejsce

$75 \quad$ Por. D. Wider, Do petni miłości, dz. cyt., s. 84.

76 Jan Paweł II, Encyklika Fides et ratio. Wstęp.

77 Por. A. Ruszała, Ze świętym Janem od Krzyża ku zjednoczeniu z Bogiem, s. 72.

78 Droga na Górę Karmel, III, 14, 2.

Por. D. Wider, Do petni miłości, dz. cyt., s. 88-90. 
Antropologia teologiczna

dla Boga. Stąd św. Jan od Krzyża przestrzegał przed niewłaściwym korzystaniem z pamięci:

Chciałbym, żeby ludzie duchowi pilnie baczyli na szkody jakie szatan wyrządza w ich duszach za pośrednictwem pamięci, jeśli się nią wiele posługują. Iluż smutków i utrapień, iluż złych i próżnych radości staje się ona powodem, zarówno w rzeczach Bożych jak i ziemskich. Przynosi nadto z sobą wiele brudów i kala nimi dusze. Oddala je natomiast od doskonałego skupienia ${ }^{80}$.

Jako władza duchowa człowieka „pamięć duchowa” ma możliwość gromadzenia, przechowywania i posługiwania się doświadczeniami uzyskanymi przez duszę na drodze mistycznego poznania ${ }^{81}$.

Ostatnią władzą duchową jest wola, która w nauce Jana od Krzyża pełni rolę swoistego centrum dyspozycyjnego, które kieruje całym dynamizmem osoby. Swoim nauczaniem Święty włączał się w filozoficzno-etyczny nurt, wskazujący kluczową rolę woli w każdym działaniu człowieka: „Siła duszy polega na jej władzach, namiętnościach i pożądaniach. Wszystkim tym zaś rządzi wola"82. Przenosząc zagadnienie woli na życie duchowe człowieka jasnym staje się, że w nim bez niego Bóg nie może niczego uczynić. Każde działanie człowieka, także na płaszczyźnie jego duchowości staje się osobowe dopiero wtedy, gdy jest kierowane przez wolę ${ }^{83}$. Na tej władzy spoczywa poważne zadanie, ponieważ ostatecznie to od niej zależy, jak człowiek wykorzysta to wszystko, co zostaje mu dane, czy będzie to użyte na jego korzyść, czy zgubę.

Święty Jan od Krzyża widział wolę człowieka w podwójnej perspektywie: rozróżniał działanie woli od uczucia woli. Pierwsze wyrażało możliwość wolnego i odpowiedzialnego decydowania o swoim życiu. Zwraca więc uwagę na jej aspekt czynny. Może być ona albo przyciągana przez coś atrakcyjnego, albo odpychana bez podejmowania jakiejkolwiek decyzji. W tym wypadku podkreśla się jej aspekt bierny. Te dwa aspekty są ze sobą powiązane: uczucie woli może płynnie przechodzić w działanie ${ }^{84}$, bądź też pozostać jedynie na płaszczyźnie wolitywnej nigdy nieprzeobrażonej w konkretny czyn. Nauczanie o woli Święty przedstawił $\mathrm{w}$ jednym $\mathrm{z}$ listów pisanych do swego ucznia:

Droga na Górę Karmel, III, 4, 2.

Por. M. Kiwka, Świętego Jana od Krzyża myśli o człowieku, dz. cyt., s. 96.

Droga na Górę Karmel, III, 16, 2.

Por. M. Kiwka, Świętego Jana od Krzyża myśli o człowieku, dz. cyt., s. 97.

Por. A. Ruszała, Ze świętym Janem od Krzyża ku zjednoczeniu z Bogiem, dz. cyt., s. 76-77. 
Ponieważ zaś rozkosz, słodycz i wszelki inny smak, który podpada pod wolę nie jest miłością, wynika stąd, że żadne z tych uczuć smakowitych nie może być środkiem proporcjonalnym do złączenia woli z Bogiem. Środkiem tym może być tylko działanie woli, które jest zupełnie czym innym aniżeli jej uczucia. Przez swe działanie wola łączy się z Bogiem i pozostaje w Nim, co jest właśnie miłością; nie można tego osiągnąć przez uczucia i pojęcia, które pozostałyby w duszy jako w swoim celu i kresie. Wszystkie te uczucia mogą tylko służyć za motyw do kochania, jeśli wola chce dalej postępować; więcej nic nie mogą

W duchowości karmelitańskiej istnieją dwie możliwości wyboru przez wolę obiektu jej zainteresowań. Pierwsza polega na prymacie woli, która sama wybiera, zaś namiętności i popędy tylko jej towarzyszą - obiekt wybierany jest rozumnie. Druga droga to ta, w której namiętności i instynkty wysuwają się na pierwszy plan, spychając wolę do roli służącej, która spełnia ich zachcianki: „I tak jest rzeczywiście. Tym bowiem sposobem wola staje się niewolnicą i traci swoją wolność, gdyż pociąga ją za sobą gwałtowność i siła zapału"86. Człowiek, którego wola jest ujarzmiona i służy niewłaściwemu obiektowi dokonuje często wielkich starań, ale tylko po to, by zaspokoić namiętności, które nim rządzą $^{87}$. Święty Jan od Krzyża miał świadomość ogromnego wpływu namiętności na wolę człowieka i starał się ją ukształtować ku większej dojrzałości, by w swoich wyborach nie kierowała się kaprysom niższych władz, lecz by we wszystkim kierowała się miłością ${ }^{88}$.

Źródłem godności sfery duchowej jest, iż poznaje ona najważniejsze, najbardziej wartościowe rzeczywistości. Ona jest także odpowiedzialna za ukazywanie człowiekowi jego celu ostatecznego i potrafi wybierać najbardziej odpowiednie środki do jego osiągnięcia. Stąd imperatywem Świętego wyrażanym we wskazywaniu drogi ku zjednoczeniu człowieka z Bogiem była praca nad przejściem ze sfery zmysłowej do duchowej ${ }^{89}$ :

O jakiż to los szczęśliwy, że dusza może się wymknąć z domu swojej zmysłowości! Moim zdaniem, może to pojąć tylko ta dusza, która tego doświadczyła. Wtedy jasno dostrzeże, jak strasznym zniewoleniem było to zniewolenie, jakiemu dotychczas ulegała, i jak wielu nędzom była poddana, gdy oddziaływały na nią jej władze i żądze, a także pozna,

Jan od Krzyża, List 13, [w:] Dzieła, Kraków 2010, s. 820.

Noc ciemna, II, 13, 3.

Por. F. R. Salvador, Święty Jan od Krzyża, pisarz - pisma - nauka, dz. cyt., s. 760.

Por. A. Ruszała, Ze świętym Janem od Krzyża ku zjednoczeniu z Bogiem..., dz. cyt., s. 78.

Por. F. R. Salvador, Święty Jan od Krzyża, pisarz-pisma-nauka, dz. cyt., s. 416. 
Antropologia teologiczna

jaką prawdziwą wolnością i bogactwem jest życie ducha, które przynosi ze sobą nieoszacowane wprost dobra ${ }^{90}$.

Teolodzy duchowości karmelitańskiej, odwołując się na nauki św. Jana od Krzyża przyrównują kształtowanie człowieczeństwa w kierunku zjednoczenia z Bogiem i podejmowania czynów temu sprzyjających do mozolnej wspinaczki górskiej: duch w powolnym procesie oswaja ciało i jego namiętności, podporządkowuje je sobie w wyniku czego obie sfery: duchowa i cielesna zaczynają ze sobą zgodnie współpracować ${ }^{91}$. Efekt tego wysiłku określany jest mianem „integracji osobowej” zdolnej do owocnego podjęcia współpracy z łaską.

\section{Nieuporządkowane przywiązania człowieka a zjednoczenie z Bogiem}

Rozróżnienie człowieka na duchowego i cielesnego, pozwoliło Janowi od Krzyża wysnuć wniosek, iż duch i ciało dążą do właściwych sobie celów, co powoduje swoiste „rozdwojenie” człowieka. Antagonizm między duchem a ciałem należy do natury ludzkiej i stanowi jej nieodłączną część. Błędem byłoby jednak stwierdzenie, że dusza i ciało stanowią dwie oddzielne frakcje, które są sobie przeciwne. Święty nauczał, że: „pomiędzy zmysłami a duchem jest ścisły związek, gdyż obydwie strony łączą się w jednym podmiocie" ${ }^{92}$. Problemem jest zachowanie właściwych proporcji we wzajemnych stosunkach. Każda ze sfer pragnie wpłynąć na drugą i podporządkować ją sobie. Pragnienia te są powodem uciążliwej walki człowieka z samym sobą ${ }^{93}$. Jedną z przyczyn takiego stanu rzeczy jest grzech pierworodny, jak również każdy grzech osobisty rozumiany jako akt wrogości i sprzeciwu wobec Boga. Gdy pragnienia realizowane są „w Bogu” wszystko zajmuje miejsce w porządku wyznaczonym przez naturę: „Gdy Bóg jest na pierwszym miejscu, wtedy wszystko jest na właściwym miejscu" ${ }^{94}$. Problem zaś rodzi się wówczas, gdy ludzie, rzeczy, zdarzenia stawiane są „na jednej szali z Nim”"95, bądź ponad Nim. Wtedy człowiek działa coraz więcej, lecz mniej doświadcza, żyje w zgodzie ze swoimi

\footnotetext{
$90 \quad$ Noc ciemna, II, 14, 3 .

Por. F. R. Salvador, Święty Jan od Krzyża, pisarz-pisma - nauka, dz. cyt., s. 415.

Por. F. R. Salvador, Święty Jan od Krzyża, pisarz - pisma - nauka, dz. cyt., S. 400-403.

Por. Droga na Górę Karmel, I, 5, 4.
} 
apetitos $^{96}$, stając się ich niewolnikiem ${ }^{97}$. W nurcie teologii duchowości karmelitańskiej zagadnienie to poruszała także św. Teresa od Jezusa:

Są w rzeczy samej dusze tak zniedołężniałe i tak nawykłe do obracania się wyłącznie w rzeczach zewnętrznych, iż straciły niejako wszelką możność oderwania się od nich choćby na chwilę i wejście w siebie stało się dla nich prawie niepodobieństwem. Ciągłe przestawanie z gadzinami i bydlętami krążącymi wokoło twierdzy przeszło u nich w nałóg i same stały sie niemal nimi ${ }^{98}$.

Jakie mogą być apetitos człowieka? Jako pierwsze św. Jan od Krzyża wymieniał dobra doczesne. Przedstawiał je następująco: „Przez dobra doczesne rozumiemy tu: bogactwo, stanowiska, urzędy i tym podobne przedmioty ubiegania się oraz dzieci, rodzinę, małżeństwo itd. Wszystko to są rzeczy, którymi wola może się radować" "99. Posiadanie tych dóbr nie musi prowadzić do grzechu, często są one jednak przyczyną odwracania się od Boga. Cały proces nieposłuszeństwa i jego skutków jest wyrażony w czterech stopniach. By przedstawić jego dynamikę Święty posługuje się słowami Pisma Świętego: „Utył Jeszurun (Izrael) i wierzga [...]. Boga, Stwórcę swego, porzucił, zelżył Skałę, swoje ocalenie” (Pwt 32, 15). Utycie „to przytępienie umysłu i zaciemnienie sądu w rozpoznawaniu prawdy i w należytym rozsądzaniu każdej sprawy podług rzeczywistego jej stanu"100. Taki człowiek staje sie coraz bardziej nieczuły na sprawy Boże: „I nie wystarczy ani świętość, ani zdrowy rozsądek człowieka, jeśli będzie pożądał rzeczy doczesnych i z nich się radował" 101 .

To przyćmienie umysłu płynnie przechodzi w drugi stopień wyrażony słowem: „wierzga”. Ma to miejsce wówczas, gdy idąc za uczuciami, człowiek przyzwyczai się do dóbr doczesnych, znajduje w nich radość, a tym samym „tłuścieje”. Taki stan rzeczy „oddala duszę od

Jan od Krzyża często używał tego. Nie definiował go jednak. Zawiera on w sobie elementy zmysłowe, intelektualne i duchowe, czyli obejmuje człowieka w całej jego złożoności. Ogólnie można przetłumaczyć to pojęcie jako pożądanie lub też jako nieuporządkowane przywiązania. Apetitos objawia się w silnym pragnieniu, które kieruje człowieka do jakiegoś dobra. Święty Jan Apostoł wskazywał na trzy główne pożądliwości: oczu, ciała i pychy. Por. A. Ruszała, Ze świętym Janem od Krzyża ku zjednoczeniu z Bogiem..., dz. cyt., s. 82-83; S. Urbański, Pożądliwość, [w:] Leksykon duchowości katolickiej, Kraków 2002, s. 694.

Por. I. Matthew, Pochwycony przez Boga, Kraków 2010, s. 73-79.

Teresa od Jezusa, Twierdza wewnętrzna, I, 1, 6.

Droga na Górę Karmel, III, 18, 1.

Tamże, III, 19, 3.

Tamże, III, 19, 4. 
Antropologia teologiczna
Boga i świętych ćwiczeń, nie smakuje już ona w nich, ma bowiem upodobanie $\mathrm{w}$ innych rzeczach. Popada w wiele niedoskonałości i niedorzeczności, kaprysów i czczych upodobań" ${ }^{102}$. Człowiek na płaszczyźnie ducha doświadcza oziębłości ${ }^{103}$, ogarnia go lenistwo duchowe, zatraca potrzebę modlitwy, jednoczenia się z Bogiem, ogranicza się do minimum, a pociechę znajduje w posiadaniu. Jest sposób życia doznaniowego, czerpiącego radość z coraz to większych przyjemności zmysłowych. W następstwie człowiek taki odwraca się od Boga, zapomina o zbawieniu. Tę kategorię tworzą:

ludzie chciwi, którzy mają tak wielkie pożądanie rzeczy stworzonych, taką z nich odczuwają radość i tak są w nich rozmiłowani, że te nie mogą ich zaspokoić. Pożądania ich raczej wzrastają ustawicznie w miarę, jak oddalają się od źródła, które jedno mogłoby ugasić ich pragnienie. Tym źródłem jest Bóg ${ }^{104}$.

Ostatnim stopniem jest „zelżenie”, czyli całkowite zapomnienie o istnieniu Boga, „wymazanie” go ze swojego życia. Boga zastępują wówczas źle używane pieniądze, które ,przebóstwione” prowadzą do „rozpaczy i śmierci” ${ }^{105}$. Oprócz tak wielkiej szkody bogactwo wyrządza także „cofanie się z drogi Bożej” ${ }^{106}$. Dotyczy to tych, którzy doświadczyli obecności Boga w swoim życiu, ale zwyciężyło w nich pragnienie „rzeczy światowych”.

Kolejną grupą dóbr pożądanych przez człowieka są dobra naturalne. „Przez dobra naturalne rozumiemy tu piękność, wdzięk, przymioty, kształtną budowę i inne dary ciała. Co do duszy rozumiemy jej dary, jak zdolności i rozsądek wraz z innymi przymiotami umysłu"107. Bóg obdarował człowieka tymi dobrami tylko po to, by za ich pomocą był poznawany i kochany. Mogą być one jednak wykorzystane niezgodnie z celem, przez co stają się obrazą Boga. Dzieje się tak, gdy służą człowiekowi do pielęgnowania i pomnażania próżności, zarozumiałości i wywyższania się nad innych ${ }^{108}$. Wówczas ,wdzięki i dary naturalne są bardzo niebezpieczne i łudzące zarówno dla tego, kto je posiada, jak i dla tego, kto je podziwia, tak, że trudno jest uniknąć usidlenia w nich

$102 \quad$ Tamże, III, 19, 5.

103 Por. A. Ruszała, Ze świętym Janem od Krzyża ku zjednoczeniu z Bogiem, dz. cyt., s. 122-123.

Droga na Górę Karmel, III, 19, 7.

Por. E. Stein, Wiedza Krzyża, Kraków 1994, s. 109.

Droga na Górę Karmel, III, 21, 1.

Por. F. R. Salvador, Święty Jan od Krzyża, pisarz-pisma-nauka, dz. cyt., s. 767. 
serca"109. Duchowa córka św. Jana od Krzyża, a jednocześnie wielki znawca jego duchowości, św. Edyta Stein wymienia konsekwencje upodobania w tych dobrach. Są to: adoracja swojej osoby, pogarda Antropologia teologiczna w stosunku do innych, podniecenie zmysłowości i częste jej uleganie ${ }^{110}$. Prowadzi to do oziębłości duchowej, podczas której „dusza w rzeczach Bożych znajduje tylko wielką odrazę, smutek, a niejednokrotnie zupełnie je sobie obrzydza"111.

Trzecią grupą działającą na człowieka, są dobra zmysłowe. Święty rozumiał przez nie ,to wszystko, co podpada pod zmysły, tzn. pod wzrok, słuch, powonienie, smak, dotyk. Również to wszystko, co jest wewnętrzną przyczyną działania wyobraźni, bo wszystko to należy do wewnętrznych lub zewnętrznych zmysłów ciała"112. Przy okazji mówienia o tych dobrach św. Jan od Krzyża jeszcze raz przypominał, że Boga nie można poznać za pomocą zmysłów. Nie trzeba koniecznie unikać wrażeń zmysłowych, jeśli człowiek nie zatrzymuje się na nich. Mogą się one bowiem stać przyczyną do dobrej modlitwy, bo jak mówił Święty: „Niektóre bowiem dusze wznoszą się do Boga raczej za pośrednictwem przedmiotów działających na uczucia" ${ }^{113}$. Gorzej dzieje się, gdy pod pozorem pobożnego życia modlitwą człowiek zaczyna się im oddawać ${ }^{114}$ :

Wiele bowiem dusz oddaje się wspomnianym wytchnieniom uczuciowym pod pozorem modlitwy i oddania się Bogu. Wtedy nie jest to modlitwa, lecz raczej wytchnienie, nie jest to spełnianie upodobania Bożego, lecz raczej własnego. Intencja wprawdzie zwraca się do Boga, ale skutki zmierzają do wytchnienia uczuciowego. Dusza odczuwa wówczas więcej słabości i niedoskonałości niż ożywienia woli i oddania jej Bogu ${ }^{115}$.

Szkody, jakie przynosi poddawanie się dobrom zmysłowym Święty przedstawiał bardzo szczegółowo, podporządkowując je poszczególnym zmysłom. Ze zbytniego przywiązania do rzeczy widzialnych rodzi się m.in. duchowa próżność, zamieszanie zewnętrzne i wewnętrzne, nieczyste myśli i zazdrośćc ${ }^{116}$. Gdy chodzi o zmysł słuchu, jego niewłaściwe wykorzystanie powoduje zamieszanie wyobraźni, nieuzasadnione

109 Droga na Górę Karmel, III, 21, 1.

110 Por. E. Stein, Wiedza Krzyża, dz. cyt., s. 110.

111 Droga na Górę Karmel, III, 22, 2.

112 Tamże, III, 24, 1.

113 Tamże, III, 24, 4.

114 Por. E. Stein, Wiedza Krzyża, dz. cyt., s. 112.

115 Droga na Górę Karmel, III, 24, 4.

Por. Droga na Górę Karmel, III, 25, 2. 
Antropologia teologiczna

i chwiejne sądy ${ }^{117}$. Z radości w „miłych zapachach” bierze się przeciwstawna nauce Chrystusa niechęć do ubogich ${ }^{118}$. Zmysł smaku i niewłaściwe z niego korzystanie budzi obżarstwo, gniew, niezgodę, osłabienie miłości wobec drugiego człowieka. Powoduje też ociężałość duszy ludzkiej, która szuka uciechy w lubieżności, co z kolei prowadzi do wielu roztargnień serca i niezadowolenia $z$ wielu rzeczy ${ }^{119}$. Jako ostatni Święty wymieniał zmysł dotyku, mówił przy tym, że:

$\mathrm{Z}$ radości w dotykaniu rzeczy miłych i przyjemnych powstają o wiele jeszcze większe, zgubniejsze szkody, tak, że w krótkim czasie wypaczają zmysły i przygaszają żywotność i siły ducha. W miarę bowiem takiej właśnie radości rodzi się zgubny występek miękkości i skłonności do niej. Stąd powstaje rozpusta, duch staje się zniewieściały i bojaźliwy, a zmysły pobudliwe i rozmiłowane w rozkoszy, skłonne do grzechu i do wyrządzania szkody. To upodobanie napawa serce próżną radością i zadowoleniem, daje swawolę językowi i wzrokowi, i w miarę jak wzrasta, odurza i osłabia wszystkie zmysły ${ }^{120}$.

Ostatecznie poddanie się zmysłowości może być powodem wielu szkód dla życia człowieka. Naukę Jana od Krzyża w kwestii karmienia się zmysłowością dobrze oddają słowa św. Franciszka Salezego: „Szkoda zasiewać rolę naszych serc tak marnymi i głupimi upodobaniami, bo zajmuje to miejsce dobrych uczuć i odwraca soki naszej duszy od dobrych skłonności"121.

Dobra moralne, przez które Święty rozumiał m.in. cnoty, czynienie dzieł miłosierdzia, zachowywanie prawa Bożego, mają już wartość same w sobie i mogą być przyczyną pozyskania innych dóbr ${ }^{122}$. Człowiek zatem powinien się o nie starać. Mogą więc być one przedmiotem jego słusznej radości, o ile odnajduje ona swoje źródło w miłości Boga: „Chrześcijanin winien się zatem radować nie tym, że spełnia dobre uczynki i naśladuje cnoty, lecz tym tylko, że czyni to dla samej miłości Boga, bez żadnego innego względu"123. Może jednak dojść do sytuacji, w której człowiek, podobnie jak ewangeliczny faryzeusz (por. Łk 18,9-14) będzie się cieszył z samego dobra moralnego i własnej doskonałości ${ }^{124}$. Powoduje to

\footnotetext{
$117 \quad$ Por. tamże, III, 25, 3.

118 Por. tamże, III, 25, 4.

119 Por. Droga na Górę Karmel, III, 25, 5.

120 Tamże, III 25, 6.

$121 \quad$ Franciszek Salezy, Filotea, 72.

122 Por. E. Stein, Wiedza Krzyża, dz. cyt., s. 114.

${ }^{123}$ Droga na Górę Karmel, III, 27, 4.

124 Por. D. Wider, Do petni miłości, dz. cyt., s. 229.
} 
szereg negatywnych następstw. W człowieku wzrasta wówczas przede wszystkim pycha i chęć pokazania siebie. Egoizm zamyka taką osobę na Boga, zaprzecza prawdę jakoby u początku każdego dobra stał Bóg. Dusza, która poddaje się tej ułudzie nie postępuje na drodze doskonałości, ponieważ nie jest zdolna do przyjęcia rad i wskazówek co do swoich czynów $^{125}$. Jedyną, właściwą postawą, jaka winna towarzyszyć człowiekowi postękującemu na drodze ku zjednoczeniu z Bogiem jest nadzieja nagrody u Boga, a nie u człowieka. Ten problem przedstawiała swoim siostrom również św. Teresa z Avilla, ucząc, że przed Bogiem nie ma nic zakrytego: „Nie sądźcie, by cokolwiek uczynicie dobrego lub złego, mogło, mimo zamknięcia, w jakim tu żyjecie, pozostać w ukryciu" ${ }^{126}$.

Piąta grupa to dobra nadprzyrodzone:

wszystkie dary i łaski udzielone przez Boga, przekraczające możność i zdolność naturalną. Określić je można jako gratis datas, darmo dane. Należą do nich dar mądrości i wiedzy, jakiego Bóg udzielił Salomonowi, jak również łaski, które wymienia św. Paweł: wiara, łaska uzdrawiania, czynienie cudów, dar proroctwa, dar rozpoznawania duchów, tłumaczenie mów i rozmaitość języków ${ }^{127}$.

Powodują one dwa rodzaje skutków w duszy człowieka: doczesne, jak np. uzdrowienia i duchowe, które zbliżają człowieka do Boga. Święty przestrzegał przed szukaniem upodobania w darach nadprzyrodzonych ze względu tylko na dobra doczesne. Mówił on, że nawet osoby pozbawione łaski uświęcającej mogą ich dokonać, bądź doznać ich skutków. Wskazywał jakby sam szatan mógł być inicjatorem tych dzieł. Możemy się więc z nich radować, tylko ze względu na dobra duchowe ${ }^{128}$.

Pierwszą szkodą, jaką ponosi człowiek, który przywiązuje się do dóbr nadprzyrodzonych jest oszukiwanie siebie i innych, życie w swoistym świecie iluzji. Przyczyną tego jest to, że człowiek nazbyt pragnie nadprzyrodzonych darów i przecenia je. Nie chce więc rozeznać czy nadzwyczajne dzieła są prawdziwe, czy fałszywe. Pobudzona namiętność popycha go do tego, by spełniał niezwykłe czyny w nieodpowiednim czasie, tym samym nadużywał łaski w niegodny i przewrotny sposób. Prowadzi to do radości z posiadanej mocy, a w konsekwencji do gotowości „kupowania łask, darów i rzeczy świętych za pieniądze”129:

Por. E. Stein, Wiedza Krzyża, dz. cyt., s. 115-116.

Teresa od Jezusa, Droga doskonałości, Kraków 1987, 15, 7.

Droga na Górę Karmel, III, 30, 1.

Por. E. Stein, Wiedza Krzyża, dz. cyt., s. 117.

Por. A. Ruszała, Ze świętym Janem od Krzyża ku zjednoczeniu z Bogiem..., dz. cyt., s. 128. 
Antropologia teologiczna

Przywiązanie do tych czynów dochodzi do takiego stopnia zła, że niektórzy ludzie nie tylko chcą kupić za pieniądze dary i łaski, jak to czynił Szymon czarnoksiężnik (por. Dz 8, 18), by przez nie służyć diabłu, lecz starają się również o posiadanie rzeczy świętych. I nie można o tym mówić bez drżenia, że jak to już widziano, zdobywali rzeczy boskie, że używali Ciała Pana naszego Jezusa Chrystusa do tak złych i ohydnych praktyk"130.

Zachwycenie posiadaną mocą i ślepa chęć korzystania z niej prowadzą do tego, że czyny nadzwyczajne nie są dokonywane mocą Boga, a szatana ${ }^{131}$. „Szatan bowiem, gdy zobaczy u ludzi skłonność ku takim rzeczom, daje im po temu szerokie pole i mnóstwo zainteresowań, mieszając się w nie sam na różne sposoby" ${ }^{132}$.

Drugą szkodą jest osłabienie wiary, które odnosi się zarówno do świadków nadzwyczajnych działań, jak i osób, które się nimi posługują: „Kto bowiem przywiązuje zbytnią wagę do tych cudownych zjawisk, umniejsza w sobie istotny i trwały stan wiary, który jest stanem ciemnym. Im więcej jest znaków i potwierdzeń wiary, tym mniej jest w niej zasługi”"133.

Brak na tej płaszczyźnie walki duchowej prowadzi do zwiększonej próżności i chełpliwości wyrażającej się w tym, że człowiek, który podejmuje jakąkolwiek pracę dla Królestwa Bożego chce, aby była ona efektowna i ceniona przez innych ${ }^{134}$.

Dobra duchowe to ostatnia grupa wymieniana przez św. Jana od Krzyża. Rozumiał on przez nie ,to wszystko, co porusza i wspomaga duszę w rzeczach Boskich, czyli w jej obcowaniu z Bogiem i w udzielaniu się Boga jej samej”"135. Chodzi tu m.in. o święte obrazy, figury, przedmioty, miejsca, święta religijne, stowarzyszenia, formy pobożności. Zajmują one uprzywilejowane miejsce w całej hierarchii dóbr, ponieważ kierują ku zjednoczeniu z Bogiem. Święty dzielił te dobra na cztery grupy: pobudzające, wzywające, kierujące i doskonalące. Zajmuje się jednak tylko dwoma pierwszymi ${ }^{136}$.

Dobrami pobudzającymi są obrazy i figury świętych oraz miejsca modlitwy i ceremonie liturgiczne. Święty przestrzegał, by z dóbr pobudzających nie stały się one hamującymi. Odnosił się do nich bardzo

\footnotetext{
130 Droga na Górę Karmel, III, 31, 5.

$131 \quad$ Por. E. Stein, Wiedza Krzyża, dz. cyt., s. 118.

${ }_{132}$ Droga na Górę Karmel, III, 31, 4.

133 Tamże, III, 31, 8.

134 Por. D. Wider, Do petni miłości, dz. cyt., s. 230.

135 Droga na Górę Karmel, III, 33, 2.
}

136 Por. E. Stein, Wiedza Krzyża, dz. cyt., s. 119-120. 
krytycznie, wypunktowywał nadużycia w posługiwaniu się obrazami i figurami: „Wiele jest takich osób, które pilniej baczą na oryginalność wykonania i wartość obrazu niż na to, co on przedstawia"137. W stoAntropologia teologiczna sunku do figur mówił, że ludzie często

ozdabiają postacie świętych strojami, które były im i muszą być wstrętne. Tak więc, razem z szatanem, usiłują kanonizować swoje próżności, wkładając je na świętych nie bez ciężkiej ich obrazy. Takim to sposobem głęboka i poważna pobożność duszy, wykluczająca sama przez się wszelką próżność, a nawet jej ślad, staje się powoli strojeniem manekinów, i to do tego stopnia, że niektórzy posługują się obrazami świętych jakby figurkami bożków, które ich radują ${ }^{138}$.

W takiej sytuacji człowiek pod płaszczem pobożności spełnia własne zachcianki i karmi swą pożądliwość.

Podobnie dzieje się w przypadku miejsc modlitwy, którymi są kaplice i kościoły. Często człowiek koncentruje się na tym, by były one przyozdobione i szuka przyjemności w zewnętrznej formie, a nie w Bogu. Analogicznie rzecz ma się z uroczystościami religijnymi, które dla niektórych stają się okazją do prezentacji własnej osoby, zabawy, lepszego jedzenia. Święty krytykował osoby, które w wyniku wypaczonej pobożności zwracają przesadną uwagę na kształt ceremonii ${ }^{139}$.

Sądzą, że jeśli jednej kropki zabraknie, lub cokolwiek opuszczą to Bóg nie wysłucha ich modlitwy. Tym samym więc pokładają więcej ufności $\mathrm{w}$ tych praktykach i sposobach niż w żywej modlitwie. Jest to wielkim lekceważeniem i obrazą Boga. Żądają na przykład, by w czasie Mszy świętej paliło się tyle, a nie mniej ani więcej świec, by ją odprawiał taki, a taki ksiądz, by była o oznaczonej godzinie, a nie wcześniej czy później ${ }^{140}$.

„Dobra wzywające” to przede wszystkim kaznodzieje i ich posługa. Święty podkreślał, że kaznodziejstwo to przede wszystkim praca duchowa niż słowna. Kazanie jest na tyle dobre i owocne, na ile kaznodzieja przeniknięty będzie Bożym duchem. Bez niego na nic zdadzą się piękne słowa i styl. Zagrożeniem w tym wypadku, jest skupianie się tylko na zewnętrznej formie przepowiadania, ponieważ wtedy nie trafia ono do ducha i nie ma możliwości na zmianę stylu życia ${ }^{141}$.

Droga na Górę Karmel, 35, 3.

Tamże, 35, 4.

Por. A. Ruszała, Zeświętym Janem od Krzyża ku zjednoczeniu z Bogiem, dz. cyt., s. 131-132.

Droga na Górę Karmel, III, 43, 2.

Por. E. Stein, Wiedza Krzyża, dz. cyt., s. 126. 
Antropologia teologiczna

Święty Jan od Krzyża nie lekceważył pośrednictwa dóbr duchowych w spotkaniu z Bogiem. W jego nauce chodzi o właściwe ich używanie, które prowadzi do głębszej zażyłości z Bogiem ${ }^{142}$.

Nieuporządkowane pożądania, nazywane przez św. Jana od Krzyża apetitos, wyrządzają człowiekowi olbrzymie szkody, zarówno w sferze duchowej, jak i cielesnej. Zniekształcają one obraz Boga w człowieku, wprowadzają niepokój i cierpienie, powodując całkowitą dezintegrację człowieka ${ }^{143}$.

Człowieka z świadomością swej grzeszności i złych skłonności św. Jan od Krzyża nie pozostawia w bezradności nad stanem swego ducha. Przekonanie o duchowej nędzy wprowadza na drogę oczyszczenia. Jest ona pełna wyrzeczeń, ewangelicznego zaparcia się siebie. Prowadzi do wewnętrznej przemiany i przygotowuje do zjednoczenia się z Bogiem, wejścia na szczyt Góry Karmel. Wypracowana przez Świętego koncepcja oczyszczenia czynnego i biernego zakłada z jednej strony zaangażowanie się człowieka, podjęcie wysiłku ascetycznego i szczegółowej pracy nad sobą z drugiej otwarcie się na działanie Boga, przyjęcie Jego łaski, całkowite poddanie się $\mathrm{Mu}^{144}$.

\section{Zakończenie}

Antropologia św. Jana od Krzyża nie jest teoretycznym rozważaniem nad człowiekiem. Wspiera się ona o osobiste doświadczenie Świętego. $\mathrm{W}$ jego świetle człowiek jawi się w realnym stanie, jaki towarzyszy mu w konsekwencji grzechu pierworodnego. Jest to stan duchowego poranienia, domagający się interwencji Boskiego Lekarza. Jego działaniu winne być poddane „choroby duszy” i wszystkie ich następstwa. Tylko w ten sposób człowiek może ujrzeć siebie w świetle prawdy i doświadczyć wewnętrznej integracji, stać się obrazem podobnym do Tego, który go stworzył.

Słowa kluczowe: teologia duchowości, duchowość karmelitańska, św. Jan od Krzyża, antropologia, ciało-dusza-duch, zmysły, apetitos, oczyszczenie.

$\overline{142}$ Por. D. Wider, Do petni mitości, dz. cyt., s. 241-242.

143 Por. A. Rachmajda, Św. Jan od Krzyża, „Pożądania oślepiaja i zaciemniaja”, „Zeszyty Karmelitańskie” 3 (2004), s. 104-106.

144 Por. P. Ogórek, Zagadnienie wyrzeczenia w nauce św. Jana od Krzyża, „Karmel” 16 (1986), s. 11-12. 